\title{
TERCÜME MAKALE/TRANSLATION
}

ISLAMI SOSYAL HIZMET UYGULAMALARI: ENDONEZYA ÖRNEĞINDE MÜSLÜMANLARIN FAALIYETLERI

Fahrudin, A., Yusuf, H., Witono, T. and Mudzakir, R. "Islamic Social Work Practice: An Expeience Of Muslim Activities In Indonesia". Islamic Social Work Practice : Experiences of Muslim Activities in Asia, ed. Kana Matsuo. (3:35-59). Shukutoku University, Asian Center for Social Work Research (ACSWR), Chiba City, 2016.

https://bit.ly/3oymnge

Yeliz BAYRAM

Dr Öğrencisi, Yalova Üniv., Sosyal Hizmet Ana Bilim Dalı Phd. Student, Yalova Unversity, Department of Social Work, Yalova/Turkey yelizkupcukbayram@gmail.com orcid.org/0000-0001-5379-448X

\section{Öz}

Insanların refahını artırmayı amaçlayan her sosyal etkinlik, aktörlerin kim olduğuna ve hangi yaklaşım veya yöntemi kullandıklarına bakılmaksızın önemlidir. Endonezya'da bu tür faaliyetler, genellikle Kyai, Üstad veya din görevlileri tarafından kullanılan camiler, gayri resmi İslami eğitim kurumu olan pesantrenler (medreseler) aracılığıyla yürütülmektedir. Bu çalışmanın amacı, Endonezyalı Müslümanlar tarafından bireylerin, ailelerin ve toplumun ihtiyaçlarını karşılamalarına ve sorunlarını çözmelerine yardımcı olmak amacıyla yürütülen faaliyetleri araştırmak ve kaydetmektir. Çalışmada nitel araştırma yöntemlerinden görüşme yöntemi ve kaynak taraması yöntemi kullanılmıştır. Birincil kaynakları dini önderler ve faaliyetlere katılan kişilerle yapılan görüşmeler, ikincil kaynakları ise konuyla ilgili daha önce yapılan araştırma raporları ve ilgili dokümanlar oluşturmuştur. Çalışmada Muhammediye, Dompet Zuafa, Pondok Remaja-Yayasan İnabah ve Mescid Terminal olmak üzere dört tür İslami organizasyon incelenmiştir. Çalışma sonuçları, Müslümanlar tarafından başlatılan "sosyal hizmet" faaliyetlerinin sosyal rehabilitasyon, güçlendirme, koruma ve sigorta gibi hemen hemen tüm sosyal refah alanlarında yer aldığını göstermektedir

Dört olgu ile örneklendirilen bu faaliyetler, sosyal refah sorunlarını ele almayı amaçlamaktadır. Bahse konu sorunlardan kaynaklanan hemen tüm problemlerin finansal çözümünde zekât, infak, sadaka veya vakıflardan yararlanıldığı görülmektedir. Bu çalışmada incelenen dört olgu Endonezya'da sürdürülen İslami sosyal hizmet faaliyetleri hakkında yaklaşık bir perspektif sunabilmektedir. Bu faaliyetler sırasında edinilen Müslüman deneyimleri, kökleri yerel geleneklere dayanan profesyonel sosyal hizmet uygulamalarını zenginleştirmek ve geliştirmek için oldukça değerlidir. [Mütercim]

Anahtar Kelimeler: İslami Sosyal Hizmet, Sosyal Hizmet Uygulamaları, Endonezya, Müslüman Faaliyetler

\section{ISLAMIC SOCIAL WORK PRACTICE: AN EXPERIENCE OF MUSLIM ACTIVITIES IN INDONESIA}

\section{Abtract}

Every social activity aimed to enhance people's well-being is important regardless of who the actors and what approach or method they use. In Indonesia, such activities are commonly conducted by Kyai, ustadz, or religious actors using faith-based institutions, mosques, or pesantren (Islamic non-formal education institution). The goal of this paper is to explore and record Indonesian Muslim activities in helping individuals, families and community to fulfill their needs and address their problems. This qualitative study used not only primary data by interviewing the actors or Islamic leaders but also secondary data, in the form of relevant previous research, 
reports and documents. Four types of Islamic organization was studied with qualitative analysis namely Muhammadiyah, Dompet Zuafa, Pondok Remaja-Yayasan Inabah and Masjid Terminal. The study results show that "social work" activities initiated by Muslims are varied in almost all social welfare domains such as social rehabilitation, empowerment, protection, and insurance. These activities represented by four cases are intended to address social welfare problems. Almost all issues arising from these social problems are financed from or facilitated by zakat, infaq, shadaqah, and waqaf. The four cases used in this study can approximately provide the picture of Islamic social work activities in Indonesia. Muslim experiences in running these activities are highly valuable to enrich and develop professional social work practices rooted in local traditions. [Translator]

Keywords: : Islamic Social Work, Social Work Practices, Indonesia, Muslim Activities

Atıf / Cite as: Fahruddin A. vd.. "İslami Sosyal Hizmet Uygulamaları: Endonezya Örneğinde Müslümanların Faaliyetleri”. çev. Yeliz Bayram. Apjir 5/1 (Nisan 2021), 106-126.

\section{Giriş}

Profesyonel sosyal hizmet çalışmaları Yahudi-Hıristiyan ve Avrupa merkezli dünya görüşü temel alınarak başlamıştır (Barise, 2003). Çok kültürlü duyarlıık, son birkaç on yıldan beri sosyal hizmet mesleğinin sahip olduğu bir değer olmuştur. (Latting, 1990; Singleton, 1994). Bununla birlikte, profesyonel sosyal hizmet uluslararasılaştığından, yerelleştirme de son yıllarda dünya çapında daha fazla kabul gören bir yaklaşım haline gelmiştir (Hokenstad, Khinduka \& Midgley, 1992). Ayrıca, giderek daha fazla sosyal hizmet uygulama modeli tarafından, danışanların dünya görüşünü anlamanın etkili sosyal hizmet için önemi vurgulandığından, sosyal hizmet eğitimine maneviyat öğretiminin entegrasyonu giderek daha fazla dillendirilmektedir. Hook, Hugen ve Augira'nın (2001) belirttiği gibi, bütüncül güçlendirme odaklı ve kültürel olarak uygun sosyal hizmet yaklaşımları kritik bir mesleki beceri haline gelir. (s.3)

Yakın zamana kadar, din, maneviyat ve sosyal hizmet konuları Endonezyalı sosyal hizmet eğitimcilerinin ve sosyal çalışmacıların nispeten az ilgi duydukları alanlar olarak görülmektedir. (Fahrudin, 2005). Dışardan bakıldığında oldukça tezat bir durum olarak görünse de bu tür konular ABD için çok daha ön planda yer almıştır (Canda, 1989; Canda, 1998; Canda \& Furman, 1999). Ulusal Sosyal Hizmet Uzmanları Birliği Etik Kuralları (NASW, 1999) bireylerin dini inanç ve uygulamalarından çok özel bir şekilde bahseder:

Sosyal hizmet uzmanları danışanlarının ve kendi kişisel ve kültürel değerlerinin, dini inanç ve uygulamalarının etik karar vermeleri üzerindeki etkisinin farkında olmalıdır. Kişisel ve mesleki değerleri arasındaki herhangi bir çatışmanın farkında olmalı ve onlarla sorumluluk çerçevesinde başa çıkmalıdır. (s.3).

Ve açıkça belirtilir ki:

Sosyal hizmet uzmanları, kişisel, dini, politik veya ticari çıkarları doğrultusunda başkalarını sömüren herhangi bir mesleki ilişkiden haksız şekilde yararlanmamalıdır. (s.9).

Endonezyalı sosyal hizmet öğrencileri ve sosyal çalışmacılar mesleki eğitimlerinde nadiren din ve maneviyatla karşılaşabilmişlerdir. Dünyanın en büyük Müslüman nüfusuna sahip Endonezya'da sosyal hizmet uzmanlarının seküler bir bakış açısına sahip olmaları çok çelişkilidir. Din hem dini kurum içinde hem de dışında insan davranışlarının temel noktası olmalıdır. Madood ve diğerlerinin vurguladığı gibi (1997) din, Güney Asya halkının büyük çoğunluğunun kendilik tanımlamasının merkezinde yer almaktadır. Buna Endonezya Müslümanları dahildir. Sosyal hizmet resmi eğitim müfredatında ve sosyal hizmet pratiklerinde İslami inanç ve uygulamaların belirtilmemesinin sebebinin, İslam'ın Müslüman sosyal hizmet uzmanı ve sosyal hizmet öğrencisiyle bütünleşmiş ve onlar için içselleşmiş bir şey olarak varsayılması olduğu düşünülmektedir. Örneğin, Bandung Sosyal Hizmet Okulu'nda müfredat, sosyal hizmet teorilerini ve uygulamalarını özümsemenin bir 
yolu olarak yerel içeriği, yerel topluluk kültürünü ve değerlerini keşfetmeye odaklanmıştır. Öğrenciler, yerel toplum değerlerini, bilgeliğini, kültürünü, sosyal ve ekonomik yapılarını anlamalarına yardımcı olması amacıyla saha çalışmalarına başlamadan önce bir haftalık kültürel eğitimden geçerler. (Fahrudin, 2013). Bu arada, İslami düşüncelerin sosyal hizmet teori ve pratiğine resmi entegrasyonu, 2005 yılında Endonezya'nın Yogjakarta kentinde bulunan "Sunan Kalijaga Devlet İslam Üniversitesi”nde “Disiplinlerarası İslami ÇalışmalarSosyal Hizmete Yoğunlaşma" adlı lisansüstü sosyal hizmet programının açılmasıyla başlamıştır. Bu program Kanada Uluslararası Kalkınma Ajansı (CIDA) ve Kanada'daki McGill Üniversitesi tarafından desteklenmiştir. Bu program oluşturulduğunda ve müfredat tasarlandığında, ülkenin sosyal hizmet eğitim ve uygulamalarında İslami düşüncelerin görülmeyişini, İslami değer ve ilkelerin Endonezya kültürünün doğal bir parçası kabul edilmesi ve bunun da sosyal hizmet uygulamalarına derinlemesine gömülü olduğu düşüncesi olarak açıklayabiliriz. Ancak, birçok tarafın İslam ilkelerinin Endonezya'daki sosyal hizmet eğitimi ve uygulamalarına resmi olarak entegre edilmesi yönünde çaba sarf ettiği de unutulmamalıdır. Proje kapsamında müfredat geliştirilirken seküler kamu üniversitelerindeki diğer sosyal hizmet bölümlerinden farklı bir müfredat tasarlanmasının gereğini ve önemini bu sürece dahil olanlar ileri sürmüşlerdir. Tarafımdan da müfredatın İslami değerler ve felsefesini içermesi ve "İslam ve Sosyal Hizmet" ilişkisini net bir şekilde vurgulayan bir dersin programda mutlaka yer alması gerektiği önerilmiştir. (Fahrudin, 2013).

Endonezyalı sosyal hizmet uzmanlarının Açe eyaletinde ve diğer bölgelerde meydana gelen Tsunami olayında yaşadıkları deneyimler de yerel dil, yerel dini uygulamalar ve gelenekleri içeren yerel kültürü ve Nahdatul Ulama (NU) ve Muhammediye gibi İslami mezheb ve İslami organizasyonların Müslüman topluluklar üzerindeki etkilerini anlamanın önemini vurgulamıştır.

\section{Araştırma Metodolojisi}

Bu çalışmada nitel araştırma metodu kullanılmıştır. Çalışma birey ve kurum olmak üzere iki grup üzerinde yapılmıştır. Sosyal hizmet faaliyetlerinin örneklemi olarak Muhammedîye, Dompet Zuafa, Pondok Remaja Yayasan Inabah ve Dewan Keluarga Mescidi seçilmiştir. Bu dört kurumun seçilme sebebi ilgili kurumların araştırmacıların erişimine açık sosyal yardım çalışmaları yürütmesidir. Bu çalışmaya ait veriler hem birincil hem de ikincil kaynaklardan toplanmıştır. Birincil veriler, seçili örneklerle yüz yüze derinlemesine görüşme ve seçkin Müslüman sosyal hizmet aktivisti, organizasyon lideri ve uygulayıcılarla yapılan odak grup tartışması metoduyla toplanmıştır. İkincil verilere yayınlanmış ve yayınlanmamış araştırma raporlarından, dergilerden, eğitim materyallerinden ve kurumların yıllık raporlarından ulaşılmıştır

\section{Sonuç ve Tartışma}

\section{İslami Sosyal Hizmet: Ulusal Genel Bakış}

Endonezya dini temelinde tek Allah inancı olan bir ülkedir. Nüfusun çoğunluğunu oluşturan Müslümanlar, inanç temelli kurum veya kuruluşlarda görülen zengin İslami gelenek ve uygulamalara sahiptir. İnanç temelli birçok kurum ve din görevlileri ihtiyaç sahipleri için "Sosyal Hizmet" faaliyetleri yürütür. Camiler, dini organizasyonlar, İslami vakıflar, hocalar (Kyai veya Üstad), dini yol göstericiler / dini önderler veya onların takipçileri bunlar arasında sayılabilir. Sundukları hizmetler genellikle deneyimlerle başlatılır ve kendileri tarafından veya mahalli olarak bilge kabul edilen önderler tarafından yönlendirilir. Yardım aktörlerinin pek çoğu dini motivasyonla teşvik edilir. Bazıları ise insancıl duygularla ya da 
Batı'lı profesyonel sosyal hizmetlerle ilişkileri olmuş olabileceğinden mesleki nedenlerle motive olurlar.

"Sosyal Hizmet" faaliyetleri, hayır işleri, nakit yardımı, mikrofinans, sosyal hizmetler, sağlık hizmetleri, rehabilitasyon, toplum ve sosyal kalkınma ve güçlendirmeye kadar değişen çeşitlilikler göstermektedir. Bu faaliyetler çoğunlukla zekât, infak (harcama) ve sadaka (gönüllü harcama) ile finanse edilmektedir. Endonezya dili (Bahasa Endonezya)'da bu araştırmada gündeme getirilen "sosyal hizmet" faaliyetleri için özel bir isim veya yerel terimler bulunmamaktadır. Zekât, infak ve sadaka gibi bazı Arapça terimler Bahasa dilinde de kullanılan ortak isimler haline gelmişlerdir. Mesela, shadaqah terimi, Bahasa diline "Sedekah" olarak girmiştir. Aynı şekilde, Arapça bir terim olan Thabib (hekim anlamına gelir) de Bahasa Endonezya dilinde "Tabib" olarak kullanılır. Genellikle bu terim Orang Pintar yerine kullanılır. Orang Pintar’ın İngilizce tam karşılığ "akıllı kişi" olmakla birlikte, aslında şaman, manevi şifacı (cenayang) ya da doğal tıp uzmanı olarak kullanılır. Kyai ve Üstad terimleri de Orang Pintar olarak kullanılabilir ancak bu terimler daha çok İslami manevi yol göstericilere veya dini önderlere atıfta bulunur.

Akademik çevrelerde, hala Batı teorileri ve uygulamalarının hâkim olduğu sosyal hizmet çalışmalarını zenginleştirme açısından, Endonezya İslam geleneklerini, iman ve inançlarını keşfetme konusunda artan bir farkındalık mevcuttur. Bu farkındalık sayesinde hem İslami değerlerin sosyal hizmetle uyumluluğuna hem de İslam'ın profesyonel sosyal hizmete katkısının dikkate alındığı görülmektedir. Bu Akimoto'nun (2013, s. 1) "Budizm profesyonel sosyal hizmete ne katkıda bulunabilir?" sorusuyla tamamen aynıdır.

Tarihte, sosyal hizmet faaliyetleri din görevlileri tarafından yürütülmüş ve Batı'da YahudiHıristiyan gelenekleri içinde büyümüştür (Zastrow, 2004). Gelişimi ise rasyonalist paradigmanın son teknolojisi olan sekülerlik olgusuna dayanan bir yardım mesleği olarak devam etmiştir (Ife, 1997). Batı sosyal hizmet felsefesi bu noktada Endonezya'nın da içinde bulunduğu gelişmekte olan ülkelere aktarılmıştır. Sonuç olarak da pek çok sosyal hizmet akademisyeni ve sosyal çalışmacı sosyal refah faaliyetlerini, Batı'nın bilimsel modern dünya görüşünü kullanarak tanımladığı sosyal hizmet mesleği sınırları içinde kısıtlama eğilimindedir.

Aslında, manevi ve dini gelenekleri de kapsayan yerel içerikleri kullanmaları kaçınılmazdır. Bu makale, profesyonel kriterlerin dışında olabilecek bazı vakaları gündeme getirmektedir. Bu nedenle çalışmada "sosyal hizmet" etkinlikleri olarak ifade edilmektedir.

Burada tartışılan birkaç vaka, Endonezya'daki İslami "sosyal hizmet" faaliyetlerine genel bir bakış bağlamında örnek olabilecektir. Muhammedîye, Nahdatu'l-Ulama (NU)'dan daha büyük ya da daha eski bir İslami organizasyon değildir. Ancak, Muhammediye, zekât, infak ve sadaka (ZiS) yönetimi ve insani yardım programlarının kullanımı konusunda NU'ya göre daha gelişmiş ve moderndir. Örneğin, Muhammedîye ve Dompet Zuafa tarafından toplanan ZIS fonları sadece hayır işleri için değil, aynı zamanda ekonomik güçlendirme, mikrofinans, rehabilitasyon, afet yönetimi, sağlık hizmetleri, yoksulluğun azaltılmasına yönelik eğitimlere kadar çeşitli programları finanse etmek için de kullanılmaktadır.

Başta Sosyal İşler Bakanlığı olmak üzere nakit transferi şeklindeki yardımlar devlet tarafından da yürütülmektedir. Nakit transferleri, PKH (Aile Umut Programı) ve ASKESOS (Sosyal Refah Sigortası) gibi koşullu veya BLT (koşulsuz nakit transferi), Raskin (yoksullar için pirinç) ve ASLUT (yaşlı sigortası) gibi programlarla koşulsuz olarak sağlanabilmektedir.

Bu programlar hem hükümet hem de sivil toplum kuruluşları (STK) tarafından "Çağdaş Batı Kökenli Profesyonel Sosyal Hizmet" olarak yürütülmektedir. 1990'lardan itibaren sayıları 
mantar gibi çoğalan bu tür STK'lar sokak çocukları için barınak hizmetleri (Rumah Singgah) gibi çalışmalar sürdürmektedir. Ancak MASTER'ın barınma hizmeti, sosyal hizmet geçmişi olmayan ancak Depok otogarında yaşayan okulu bırakmış çocuklarla büyüdüğünden bireysel farkındalığa sahip bir Üstad tarafından yönetildiği için oldukça farklıdır. Bu vakıf, faaliyetlerinde sosyal hizmet öğrencisi olan gönüllüleri kullanmaktadır. Pondok İnabah örneğinde ise farklı inanç temelli kurumlar veya manevi önderler uyuşturucu bağımlılarını, genç suçluları ve akıl hastalarını iyileştirmeye yönelik çabalar göstermektedir. Uyuşturucu bağımlılarının sayısının yıldan yıla arttığı Endonezya'da yapılan bu faaliyetler oldukça faydalı olmakta ve önemli katkılarda bulunmaktadırlar. 2007 yılında Sağıı Bakanlığı tarafından yapılan temel sağlık anketine göre, zihinsel-duygusal bozukluğu olan kişilerin oranı sadece \%0,46 iken, ciddi zihinsel sorunları olan kişilerin oranı \%11,6'ya ulaşmıştır. Son zamanlarda, hükümet psikotrop maddelerin yayılmasının önüne geçmeye çalışmalar yapmaya ve aynı zamanda uyuşturucu bağımlıları için rehabilitasyon merkezleri açmaya başlamıştır. Söz konusu uyuşturucu bağımlılarının rehabilitasyonunda özel kurumların da rol almaya başlamasına rağmen hizmetler hala sınırıdır.

$\mathrm{Bu}$ nedenle, Pondok İnabah Suryalaya ve manevi şifacılar gibi aracıların varlığı çok önemlidir. Genellikle, Endonezya toplumunun ülkedeki Müslümanların çoğuyla benzer inançları vardır. Nelson'a (2009) göre, zihinsel-duygusal bozuklukların inançsal zayıflıklar gibi manevi ya da doğaüstü durumlardan kaynaklandığına inandıklarından müdahalenin de manevi ve dini yöntemlerle olması gerekmektedir. Bu nedenle, hastalar, şikâyeti olanlar ve diğer kişileri oluşturan önemli bir kısım manevi/dini önderlerine veya geleneksel şifacılara başvurma eğilimindedir.

Yukarıdaki örneklerle karşılaştırıldığında, hükümet tarafından yürütülen programlar kapsam olarak daha çeşitli ve evrenseldir. Örneklerdeki aracıların çabaları ise düzensiz ve genellikle coğrafi olarak sınırlıdır. Ancak devletin yeterlik ve kapasitesi de sınırlı; şirketlerin sorunlara ilgi ve katılımları belirsizdir. Bu noktada, "sosyal hizmet" faaliyetleri, mevcut hükümet programlarını tamamlamanın yanı sıra bürokratik ve idari engelleri aşmaya yönelik grupların bütünleşmesine yardımcı olmak için gerekli ve çok değerlidir. Ayrıca, toplumun, sosyal sorunların çözümüne yönelik bir sorumluluk alma biçimi olarak da algılanabilir. 2009 tarihli Sosyal Refah Yasasının 11. Maddesinin öngördüğü gibi, hükümetin yanı sıra, toplum üyeleri de kendilerini sosyal refah faaliyetlerine dahil etme sorumluluğuna sahiptir.

\section{Endonezya'da Müslümanların "Sosyal Hizmet” Faaliyetleri}

Endonezya'da muhtaçlara yönelik "Sosyal Hizmet" faaliyetlerini yürüten pek çok inanç temelli kurum ve dindar insan bulunmaktadır. Hizmetlerini genellikle tecrübeleri ve kişisel görüşleri doğrultusunda sunmaktadırlar. Aralarından bazıları ise profesyonel olarak yardım hizmeti eğitimi almış, sosyal hizmet bölümü mezunu olup inanç temelli kurumlarda çalışanlardır. Endonezya'da, modernite ve ilerici hareketlerle karakterize olmuş büyük İslami kurumlardan biri Muhammediye'dir. Bu organizasyon, düzensiz bireysel faaliyetlerin yanı sıra yetimler, yoksullar, çocuklar, engelliler (fiziksel ve zihinsel), yaşlılar ve diğer sosyal açıdan dezavantajlı gruplar için sosyal hizmet veren çeşitli kuruluşlara sahiptir. Sosyal hizmet faaliyetlerinin sadece din görevlileri tarafından değil, İslami değerlerin, inançların ve ilkelerin pratikte bütünleştiği dini yaklaşımlarla da yürütüldüğünü belirtmek gerekir. Illginçtir ki, sunulan hizmetlerden sadece Muhammediye üyeleri değil, Muhammediye takipçisi olmayanlar ve gayrimüslimler de faydalanabilmektedir.

\section{Olgu 1: Muhammediye Sosyal Hizmet Uygulama Modeli}


Endonezya gibi gelişmekte olan Müslüman ülkelerin çoğunda sosyal hizmet uygulaması, mesleki pratiğin evrensel olduğu inancıyla Batı modelini izlemiştir. Ülkede elli yıllık sosyal hizmet uygulamasından sonra, söz konusu model dini değerleri ve maneviyatı dışladığı için büyük oranda başarısız olmuştur. Son on yıl içinde batılı profesyoneller, sosyal hizmet pratiğinin verimsizliğinin teori ve metodolojide maneviyat ve dini ögelerin yokluğundan kaynaklandığını fark etmiştir. Arapça "Muhammed'in takipçileri" anlamına gelen Muhammediye Endonezya'da kurulu, İslami bir organizasyondur. Organizasyon Kur'an'da yer alan surelerden biri olan Maûn Suresi'nin anlam ve yorumuna dayanan reformist bir sosyo-dini hareket olarak, 1912 yılında KH Ahmad Dahlan tarafından Yogyakarta şehrinde kurulmuştur. (Nashir, 2010). Surenin temel anlamı, yoksul ve yetim olanlara yardım etmektir. Muhammedîye, Endonezya'nın her yerine -ulusal seviyeden topluluk seviyesineyayılmış 29 milyon üyesi ile, Endonezya'nın en büyük ikinci İslami organizasyonu konumundadır. Muhammedîye, siyasi parti olmayan, kendisini sosyal ve eğitimsel faaliyetlere adayan bir yapı olmasına rağmen Endonezya'nın siyasetini aktif olarak şekillendirmektedir. Muhammedîye şu anda yaklaşık 8.000 eğitim tesisi, 450'den fazla sağlık hizmeti birimi, 11.000 dini tesis ve savunmasız gruplar için 500 konutluk tesisler de dahil olmak üzere birçok hayır kurumunu ve hizmeti yürütmektedir.

Mayıs 2013'te Muhammedîye ve uluslararası bir STK olan Family for Every Child (Her Çocuk İçin Aile), mevcut sistemde iyi uygulama örneklerini tanımlamayı ve geliştirmeyi amaçlayan sosyal hizmet değerlendirme aracı üzerine bir pilot çalışma yürütmüştür. Bu pilot proje, Emily Delap, Profesör Andy Bilson ve danışman Adriana Pacheco Graham gibi Family for Every Child politikasının başında bulunanlar tarafından desteklenmiştir.

Değerlendirme aracı, kırılgan çocuklar ve aileler için hizmet sunumunu iyileştirmek amacıyla sosyal hizmet sistemi içindeki güçlü yönlere dayanacak şekilde tasarlanmıştır. Olumlu deneyimlere odaklanan ve iyi uygulamalara dayalı yansıma ve eylemleri teşvik eden olumlu sorgulama yaklaşımı kullanır (www.familyforeverychild.org).

İki haftalık program, eğitim, odak grupları aracılığıyla alan testleri, önemli paydaşlarla yapılan görüşmeler ve toplantıları içermekteydi. Brezilya'da yapılan bir önceki pilot uygulamadan çıkarılan dersler üzerine inşa edilmiştir. Bu süreçte Muhammedîye, kendi sosyal hizmet uygulamalarında ele almak istedikleri çeşitli sorunları tespit etmiştir. Özellikle, Muhammediye'de çalışan ve yatılı bakım ile diğer hizmetleri sunan sosyal hizmet görevlilerinin, aileleri kendi çocuklarına bakmaları yönünde destekleyecek donanıma sahip olmalarının sağlanmasını ve böylece kurumsal bakıma bağımlılığın azaltılmasını sağlamak istemektedirler.

\section{Model 1: Muhammediye Çocuk Bakım Programı}

Muhammedîye hareketinin en büyük sosyal hizmet faaliyetlerinden biri çocuk bakım merkezidir (Panti Asuhan Muhammedîye). Panti Asuhan Muhammedîye, onlar toplumda yaşamaya hazır olana kadar çocukların büyüme ve gelişimini desteklemek için yatılı bakım ve diğer hizmetleri sunmaktadır. Panti, çocuk hizmetlerinin yanı sıra, ailelerin kendi çocuklarına bakmalarını da destekleyerek kurumsal bakıma olan bağımlılığı azaltmaktadır.

\section{Model 2: Muhtaçlar İçin Muhammediye Yardımı (Zekât)}

Daha önce de belirtildiği gibi Muhammediye, 1912 yılında KH Ahmad Dahlan tarafından Endonezya'da Yogyakarta şehrinde İslami bir organizasyon olarak, Kur'an'daki surelerden biri olan Maûn suresinin mealine dayanan reformist bir sosyo-dini hareket olarak kurulmuştur (Nashir, 2010). 
Muhammediye'nin Jogjakarta bölgesinde il (wilayah) düzeyinde veya ilçe (kabupaten/daerah) düzeyinde zekât kurumu bulunmamaktadır. Bu araştırma, Jogjakarta bölgesinde zekât uygulaması için gerçekten operasyonel bir kurum olan BAPELURZAM (Badan Pelaksana Urusan Zakat Muhammadiyah: Muhammediye Zekât Operasyon Organı) ile alt bölge (kecamatan/cabang) düzeyinde gerçekleştirilmiştir. Bununla birlikte, bu bölgede zekât uygulaması, ilçe, belde ve hatta en alt düzeyde bile yapılabilir. Bu nedenle, araştırmamız Kabupaten Sleman'da Kecamatan Gamping'de, BAPELURZAM Kauman ve Kelurahan Nogotirto 'da yürütülmüştür.

\section{Yogyakarta Bölgesinde Zekât Kurumu}

Muhammadiyah organizasyonunun ideal konseptinde, ulusal düzeyde zekât, harcama ve hayırseverlik/gönüllü harcamalar için operasyonel kurum olan LAZis (LembagaAmil Zekât, Infak ve Sadaka) (Pimpinan Pusat Muhammadiyah), yerel düzeyde ise Lembaga Amil Zekât (LAZ) bulunur. Illçeler (kabupaten ve kecamatan) düzeyindeki BAPELURZAM ise Muhammediye'de, ranting/kelurahan düzeyinde muzakki (zekât ödeyen kişi ya da kurum) ve müstahak (zekât kabul etme hakkına sahip kişi ya da grup) ile doğrudan temas halindeki operasyonel koordinatörlerden oluşur.

BAPELURZAM, Gamping, Muhammediye'nin Jogjakarta bölgesinde en iyi bilinen zekât kurumudur. Bu nedenle, araştırmamız esas olarak bu alt bölgeye odaklanmıştır. Bu kurum Kelurahan Nogotirto'da küçük bir zekât kurumu olarak kurulmuştur. Kurum yönetiminin Kecamatan Gamping'de daha geniş bir alanda gelişme planları vardı. 1998 yılında, 1979 yılında kurulan Zekât uygulamasında Muhammediye için en iyi bölge olarak bilinen Weleri, Kendal (Orta Java) ' da karşılaştırmalı bir çalışma yaptılar.

\section{Zekât: Kavram ve Uygulama}

Yaptığımız araştırmada zekât kavramının temel unsurları üzerinde durulmuştur. Bunlar zekât, müddet, nisap, yüzde/oran, muzakki ve müstahak kavramlarının tanımı ve konseptini kapsamaktadır. BAPELURZAM Gamping ve Kendal zekât konusunda aynı kavram ve işlemleri uygularlar. Kur'an-ı Kerim'in bazı ayetlerine (Bakara: 277, 43; Tevbe: 35,103 ) ve bazı hadislere (Buhârî'den ve Müslim'den İslam'ın beş şartı) dayanarak zekâtın İslam'ın beş şartının üçüncüsü olduğuna ve her Müslüman için bir zorunluluk olduğuna inanmaktadırlar. Bu nedenle zekât ödemeyi reddedenleri kafir/ mürted (İslam'dan çıkmış) olarak nitelendirmektedirler. Zekât, infak, sadaka, hibe (hediye) ve vakıftan farklıdır. BAPELURZAM'ın zekât kavramı "zakat amwal" yani "servetin/malın zekâtı" olarak adlandırılır. Sahip olduğumuz tüm mal ve servetin, sadece altın-gümüş, hayvanlar ve tarım ürünleri, ticari ve benzeri ürünler gibi sektörel varlıkların değil, aynı zamanda arsalar, evler, arabalar, motosikletler, mobilyalar ve bunlara benzer mülklerin de zekâtı verilebilir. Zekât müessesesinde yaşanan başarısızlığın nedeninin sektörel zekât uygulaması olduğunu savunmaktadırlar. Zekât her yıl (yıllık şekilde) ödenir. Tarım ürünleri için her hasat zamanı değil yıllık olarak yüzde \%2,5 oranında ödenmektedir. Nisap geleneksel olandan oldukça farklı olarak zekât alanındaki başarısızlığın en olası nedenlerindendir. Zekât, sadaka-i fıtır ve kurban gibi ibadetler için konulan bir zenginlik ölçüsüdür. Nisap, bir kişinin toplam borcundan ve aslî ihtiyaçları için gerekli miktardan malı çıkarıldığında kalan miktardır. Eğer kalan miktar sıfır ise kişi nisap miktarına ulaşamaz.

Müzekki, toplumda nisap miktarını aşan zenginliğe sahip olduğu kabul edilen bir Müslüman ya da aile reisidir. Müstahak ise Kur'an-ı Kerim'de Tevbe Suresi 60. Ayette sekiz grup olarak belirtilmiş; zu'afa -miskinler ve sebilillah -Allah yolunda savaşanlar olarak iki büyük gruba ayrılmıştır. Toplanan zekâttan organizasyon için belli bir pay ayrılmaktadır. Uygulamada zekât ödemek her müzekkinin kendi farkındalığına dayanmaktadır. Müzekki 
veya müstahak, kavramları ile Muhammediye, Nahdatul Ulema (NU) veya Persatuan İslam (PERSiS) gibi organizasyonlarla ilişkilerine bakılmaksızın, bir bölgede yaşayan tüm insanlar kastedilmektedir. Zekât her yıl ramazan ayında toplanır ve Şevval ayında dağıtımı yapılır. Müzekki BAPELURZAM'a bildikleri bazı müstahakları önerir. Ardından BAPELURZAM yetkilileri, PCM lideri (pimpinan cabang) ve toplumun dini önderlerinin aldıkları karar ile toplanan miktar müstahaklara dağıtılır. Toplanan zekâtın \%15'i BAPELURZAM'a ayrılır ve \%10'u Daerah (illçe), \%3'ü Wilayah (il) ve \%2'si Pusat (Merkez) bazında dağıtılır. Kalan zekât (\%85) ise müstahaklara bir miktar paraya eşdeğer kredi veya tüketim aracı olarak dağıtılır.

\section{Model 3: Muhammedîye Afet Yardımı}

Muhammediye Afet Yönetim Merkezi (MDMC) 2007 yılında "Afet Yönetimi Merkezi" adı altında çalışmalarına başlamış, daha sonra Muhammediye'nin afet önleme faaliyetlerinde kaynaklarını koordine etmekten sorumlu kurumu olarak belirlenmiştir. 2010 yılında Muhammedîye Yönetim Kurulu tarafından tanınmıştır. MDMC, afet yönetimi faaliyetlerinin tanımına uygun olarak afet yönetimi işlevlerini Afet Riskini/Etkilerini Azaltma ve Afete Hazırlık, Acil Müdahale ve Rehabilitasyon süreçleri kapsamında yürütmektedir. MDMC, insani yardım ve insani yardım şartına uyumlu uluslararası geçerliği olan gönüllülük kurallarını benimsemiş, Hyogo Çerçeve Eylem Planı ile uyumlu afet riski azaltma misyonunu oluşturarak 100 yıllık Muhammediye hareketinin temelini oluşturan, topluluklarda, okullarda ve hastanelerde temel seviyede afete hazırlık düzeyi gerçekleştirmiştir. MDMC, Persyarikatan Muhammediye Bölgesel Yapılanması operasyonlarını faaliyetlerini MDMC Muhammediye Bölge Yönetimi (il bazında) ve MDMC Muhammediye Kısım Yönetimi (ilçe bazında) şeklinde yürüterek tüm Endonezya topraklarında afet yönetim faaliyetleriyle meşgul olmaktadır.

\section{Olgu 2: Dompet Zuafa (Fakirlerin Cüzdanı) Vakfı}

Fakirlerin cüzdanı anlamına gelen Dompet Zuafa, Endonezya'nın günlük büyük gazetelerinden REPUBLiKA'da çalışan bir grup genç gazeteci tarafından kurulmuştur. Endonezya'daki yoksulluk sorunları konusunda çok endişeli olan Parni Hadi, Haydar Bagir, S.Sinansari Ecip ve Eri Sudewo adındaki dört genç gazeteci bir araya gelerek yönetim kurulunu oluşturdukları Dompet Zuafa Republika adında yeni bir oluşum meydana getirmişlerdir. Muhtaç insanlara kendi maaşlarından bağış yaparak sürdürdükleri yardım faaliyetlerini yerel gazetelerde yayınlamışlardır. Dompet Zuafa'nın toplumu güçlendirme ve geliştirme programıyla ilgili ilk haber 2 Temmuz 1993'te yayınlanmıştır.

Okuyucular yardım programı haberlerine tepki olarak gazeteye bağışlar yapmışlar, gönüllü çalışmalara destek verme teklifinde bulunmuşlardır. O zamandan beri Dompet Zuafa, Endonezya'daki yoksul insanların ve marjinal toplulukların güçlendirilmesi ve geliştirilmesine yardım etmektedir. Dompet Zuafa'nın fikir, faaliyet ve programları Endonezya takımadalarına yayılmıştır. Hale hazırda Dompet Zuafa'nın fikir ve etkinlikleri yurtdışında Çin Halk Cumhuriyeti (Dompet Dhuafa Hongkong), Avustralya (Dompet Zuafa Avustralya) Japonya (Dompet Zuafa Japonya) ve Amerika Birleşik Devletleri (Dompet Zuafa $A B D)$ gibi birçok ülkede devam etmektedir. Dompet Zuafa ayrıca, zekât, infak, sadaka ve vakıftan yoksul topluluklara yönelik acil durum ve afet, ekonomi, sağlık ve eğitim yardımı gibi çeşitli insani yardım programları için bağış toplama ve finansman sağlama işleri de yürütmektedir. Olgu 3: Uyuşturucu Kullananlar İçin Psiko-Manevi Terapi: Pondok
Pesantren Inabah Suryalaya 
Pondok Pesantren Suryalaya, 1956 yılında 120 yaşında ölen Şeyh Abdullah Bin Hacı Nur Muhammed tarafından 5 Eylül 1905'te kurulan İslami bir eğitim kurumudur. Bu kurum, Batı Java eyaletinin başkenti Bandung'a yaklaşık $90 \mathrm{~km}$ uzaklıktaki Tasikmalaya'da yer almaktadır.

Eğitime ek olarak, Pondok Pesantren Suryalaya, toplum hizmetleri aracılığıyla temel fonksiyonu olan iyiliği teşvik etme ve kötülükten menetme (Emr-i bi'l ma'rûf ve nehy-i anil münker) görevini de yerine getirmektedir. Pondok Inabah, Pondok Pesantren Suryalaya'nın uyuşturucu bağımlıları için rehabilitasyon merkezi olarak hizmet veren bir parçasıdır. Pondok Pesantren Suryalaya'da, bağımlı kişiler kurumda resmi dersi takip etme izni verilmeden önce rehabilitasyon için özel bir merkeze yerleştirilirler. (Nasution, 1990).

İnâbe rehabilitasyon merkezinde uyuşturucu bağımlılığından muzdarip olanlar için Kadrilik, Nakşibendilik ve Sufilik yöntemlerinden zikir ve dua ile tövbe ve ibadet faaliyetlerini içeren İslami psikososyal yaklaşım kullanılır. Tedavi ve rehabilitasyonun odak noktası ruhtur. Yöntem, olumlu ve yönlendirilmiş bir davranışın temiz ve saf bir ruhtan kaynaklandığına inanmaktadır. Bu nedenle, İnabah'ın temel hedefleri, Kadiri, Nakşibendi ve Sufizmin (Emo Kastama, 1990) amaçlarına uygun olarak şu şekilde sayılmaktadır:

Takarrub, Allah'a yakınlık; çünkü Allah kullarına daha yakındır, Marzatillah, Allah'ın kutsadığı bir yaşam tarzına kavuşmaktır. Bu yol, münzevi, nazik, bağışlayıcı ve sevgi ile Mahabbah (muhabbet) ve marifah (marifet)'e götüren kaliteli ve olumlu tutumlara yol açar. Muhabbet, Allah'a sevgi ve itaat duygusudur. Öte yandan, marifet bilmek veya tanımak anlamına gelir.

İnâbe rehabilitasyon merkezinde zikir (Allah'ın büyüklüğünü hatırlamak ve zikretmek) uyuşturucu rehabilitasyon sürecinde kullanılan yöntemlerden biri olarak kabul edilir. Zikir, sadece dille yapılan bir ibadet değil insanların kalbini, davranışlarını ve hareketlerini iyileştiren, insanlara güçlü bir güven aşılayan bir ibadettir. Namazlardan sonra en az 165 defa tekrarlanmak suretiyle uygulanır. Zikrin oluşturduğu Allah'a takarrub (yakınlık) ve muhabbet (sevgi ve itaat) duygusunun, uyuşturucu bağımlılığına yol açan şeytani tutku ve cazibelerle mücadele etmek için gerçekten önemli olduğuna inanılmaktadır.

PRI, uyuşturucu bağımlılarına, suçlu gençlere ve akıl hastalığı olan kişilere çoğunlukla Kadiri ve Nakşibendi tarikatının tasavvufi yöntemlerinden yararlanarak yardım etmektedir. Yaklaşımın altta yatan temel ilkesi, zihinsel ve davranışsal sorunları olan insanların problemlerinin köklerinin tanrının emir ve iradesine itaatsizliklerinden kaynaklanıyor olmasıdır. Rehabilitasyonda kullanılan yöntemler arasında yıkanma, dua etme, zikir (Kur'an-ı Kerim kelimeleri/hecelerinin yüksek sesle ve tekrar tekrar makam ile okunması) ve zihinsel rehberlik bulunur. PRI kuruluşundan bu yana binlerce uyuşturucu bağımlısı, suçlu ve zihinsel bozukluğu olan insanı başarıyla sıkıntılarından kurtarmıştır.

\section{Olgu 4: Terkedilmiş Çocukların Master Depok Camisinde Eğitimi}

Sekolah Terminal Mescidi (Sekolah MASTER olarak kısaltılır) sokak çocukları, sokak satıcıları ve Batı Java Depok kasabasındaki otobüs terminalinde ve çevresinde yaşayan, yoksul ebeveynlerinin terkettiği çocuklar için alternatif ve ücretsiz bir okuldur. Terminal Mescidi adı başlangıçta faaliyetlerinin, otobüs terminalinin hemen yanında bulunan küçük bir caminin (Bahasa dilinde Mescid) terasında başlaması nedeniyle buraya atıfta bulunmak maksadıyla kullanılmıştır. 2003 yılında, küçük cami yenilenmiş ve artan sayıda öğrenciye hitap etmek için daha büyük bir cami haline getirilmiştir. 2011 yılında, ulusal bir madencilik şirketi tarafından vakıfta okul ve öğretmen odaları olarak kullanılmak üzere bazı konteynerler bağışlanmıştır. MASTER okulu, 2000 yılında kurulan ve 2002 yılında halk 
eğitim merkezi (Pusat Kegiatan Belajar Mengajar Masyarakat --PKBM) olarak faaliyete başlayan YABIM (Yayasan Bina Insan Mandiri) adlı bir vakfa bağlıdır. Bu okul, zengin Müslümanlar tarafından kamu yararına kullanılma maksadıyla veya dini amaçla bağışlanan vakıf toprakları üzerine inşa edilmiştir. MASTER okulunun da başkanı olan Nurrohim adındaki üstad bu okulun ve vakfın temel figürüdür. Subandono'ya (2011) göre bu okul, kurucusunun sokakta yaşayan ya da zamanının çoğunu halka açık yerlerde geçiren çocuklar için endişelenmesi nedeniyle kurulmuştur. Bu çocukların çoğu terk edilmiş, evsiz, sokak şarkıcılığı veya sokak satıcılığı yapan okuldan ayrılmış çocuklardır. MASTER, okul öncesi eğitimden başlayarak çeşitli seviyelerde eğitimler yürütmektedir; ilkokuldan liseye kadar eşitlenmiş eğitim paketleri (Paket Penyetaraan A, B, C); açık ortaokul ve lise, işletme Okulu ve Sanat Okulu bu eğitimler arasındadır.

MASTER okulu öğrencilerinin sayısı binlere ulaşabilmektedir. Bazı araştırmacıların ulaştığı veriler okulda yaklaşık 1200, 2010 yılında tam 1147 öğrenci olduğunu göstermektedir. (Subandono, 2011; Tamba, 2012). Vakıf, eğitimin yanı sıra barınma, sosyal hizmet, sağlık hizmeti ve ekonomik destek hizmeti de sağlamaktadır. Öğretmenlerin ve personelin bir kısmını MASTER mezunları, diğer kısmını yerel yönetimin görevlendirdiği öğretmenler, sosyal / eğitim aktivistlerinden gönüllüler ve üniversite öğrencileri oluşturmaktadır. Bu hizmetlerin yürütülmesi için gerekli finansman ve kaynaklar çoğunlukla bağış, vakıf, infak ve sadaka şeklindeki sosyal desteklerden sağlanmaktadır. Ayrıca, yerel yönetim, vakıf tarafından yürütülen ekonomik faaliyetler, BAZNAS (ulusal zekât toplama organı) ve kurumsal sosyal sorumluluk projeleri gibi eğitimle ilgilenen bazı kuruluşlardan da destek sağlanmaktadır. (Subandono, 2011; Tamba, 2012). Subandono (2011), MASTER okulu yönetimi tarafından kullanılan özveri (pengabdian), samimiyet (keikhlasan) ve minnettarlık (keberkahan) ilkeleri üzerinde ısrarla durmaktadır.

Subandono tarafından açıkça belirtilmese de bu üç ilkenin İslami öğretilerden feyiz aldığı görülmektedir. Pengabdian (özveri) prensibi gereği, başkan "bu hayatın bir fedakârlık olduğunu ve her şeyin bize geri döneceği inancını taşımamamı gerektiğini” dile getirmektedir. (Subandono, 2011, s. 79). Keikhlasan (samimiyet) ile ilgili olarak da "... varlığımızla ilgili olarak, içtenlikle bir şeyler yaparsak, hiçbir fedakarlığın faydasız olmadığına dair inancımızı yükseltmemiz gerektiğini ifade etmiştir. (s.80). Dahası, okul müdürü bu alanın onların cihat (kutsal savaş) sahası olduğuna inanmaktadır. Ona göre cihat cehâlet ve yoksulluğu ortadan kaldırmaktır" (s.81). Keberkahan (minnettarlık) ise MASTER okulu yönetimi tarafından “... iyi ve olumlu bir düşünceye sahip olduğumuzda, iyi şeyler yaparız ve eğer Allah isterse, iyilik artacaktır" şeklinde sunulmaktadır (s.82).

\section{Endonezya'da Müslüman Liderler ve Takipçileri Tarafından Gerçekleştirilen "Sosyal Hizmet” Faaliyetlerinin Görünümü}

Endonezya, nüfusunun çoğunluğu Müslüman olmasına rağmen ne bir İslam ülkesidir ne de laik bir ülkedir. Temelinde Allah'ın bir olduğu inancı yatan, gelişmekte olan bu ülke, inanç temelli organizasyonların ve sosyal hizmet çalışmaları yapan dindar kimselerin temsil ettiği zengin İslami geleneklere sahiptir. Bu gelenekler hayır işleri, yoksulluğun azaltılması, güçlendirme faaliyetleri ve muhtaç kişiler için sosyal hizmetlere varan çeşitliliktedir. Batı'da sosyal hizmetin ortaya çıkışına benzer şekilde, Endonezya'da da bu tür faaliyetler, Müslüman liderler (kyai), dini yol göstericiler (üstad) ve onların takipçileri gibi dini figürler tarafından yürütülmektedir. Bu iyi uygulamalar motivasyon, İslami inanç ve değerlere tutunma ile oluşturulabilir. Örneğin, İslam'ın beş şartından üçüncüsü olan zekâtın, ibadet ve sosyal sorumluluk olarak iki ayağı vardır. İmkânı olanlar her yıl sahip oldukları kaynakların \%2,5 ila \%10'unu yoksullara vermelidir. Bu uygulama, hayırsever nüanslarla birlikte Endonezya'daki sosyal adalet ve ekonomik dağıtımın desteklenmesine katkıda 
bulunan sosyal refah faaliyetlerinden biridir. Başka bir örnek, ruh hastalığı veya yaşam sorunları olan kişilerin psikiyatristlere veya sosyal hizmet sunan kurumlara gitmek yerine yardım için manevi önderlerine gitme eğiliminde oldukları gerçeğinden kaynaklanmaktadır.

Endonezya sosyal hizmet prensiplerini, diğer gelişmekte olan ülkeler gibi 1960 'lardan 1970 'lere kadar Batı'dan ithal etmiştir. O zamandan beri, hatta bugün hala uygulanan profesyonel sosyal hizmetin temelinde bu prensiplerin olması nedeniyle pratikte dini ve manevi unsurlar ortadan kalkmış gibidir. Ancak, günümüzde bazı uzmanlar ve sosyal hizmet çalışanları arasında bu unsuru sosyal hizmete entegre etme konusunda artan bir farkındalık görülmektedir.

\section{Cami Üstadları ve Din Görevlilerinde / Kurumlarda Çalışanlarda Motivasyon Kaynakları}

Bir cami aktivisti, dini bir organizasyona mensup iki kadın aktivist, yetimhane ve okul sahibi olan bir çift gibi farklı geçmişleri olan beş katılımcıyla yapılan görüşmelerde, hayırseverlik veya sosyal faaliyetler düzenleme nedenlerini açıklayan çeşitli ortak temalar tanımlanmıştır. Görüşmeye katılanların bu davranışlarına sebep olarak sundukları nedenlerin normatif gerekçelerin ötesine geçtiğini ve hükümetin vatandaşlarına refah sağlamadaki rolünü de içerdiğini görmek şaşırtıcıdır.

Müslüman önderler ve takipçilerinin "sosyal hizmet" çalışmaları yürütmesine neden olan çeşitli motivasyon kaynakları vardır. Çoğu, bir Müslümanın diğerine, özellikle de muhtaç ve zayıf olanlara yardım etmesi gerektiği yönündeki İslami öğretiler nedeniyle ihtiyaç sahiplerine hizmet etme motivasyonuna sahiptir. Dini motivasyon da aralarında yaygındır. Allah sevgisi ile ya da yüce Allah (lillahi te'ala)'tan sevap kazanmak için doğru şeyler (sâlih amel) yapmak gereklidir. Bunların yanı sıra, insanlık ve fedakârlık duygusu gibi profesyonel motivasyonları da olabilmektedir. Nitekim Kur'an ayetlerinde ve peygamber sözlerinde (Hadis) Müslümanların bu konudaki yükümlülüğünün altını çizen çeşitli vurgular mevcuttur. Katılımcılar tarafından en çok referans alınan Kur'an- Kerim'de bulunan 7 ayetten oluşan Maun Suresi'dir.

\footnotetext{
Gördün mü, o hesap ve ceza gününü yalanlayanı! (1) İşte o, yetimi itip kakan(2) yoksula yedirmeyi özendirmeyen kimsedir.(3) Yazıklar olsun o namaz kılanlara ki (4), Onlar namazların ciddiye almazlar.(5) Onlar (namazlarıyla) gösteriş yaparlar.(6) Ufacık bir yardıma bile engel olurlar.(7)

Have you seen him who belies the rewards and punishments (of the Hereafter?

(1) He it is who drives away the orphan (2) and does not urge giving away the food to the poor (3) Then woe to the praying ones (4) who are careless of their Prayer (5) who do good to be seen (6) and withhold small kindnesses (from the people)(7)(Al Maududi, Tafhim al-Qur'an http://englishtafsir.com/Quran/107/index.htm
}

Yukarıdaki ayetlerde yetim ve yoksul kelimelerinin tam mana karşılıkları ile geçmesi, bu iki grubu Müslümanların yürüttüğü sosyal hizmetlerin merkezine yerleştirmiştir. Bu nedenle yetimhane kurulması, Endonezya'daki çoğu İslami organizasyon tarafından yapılan yaygın bir faaliyettir. Kur'an'ın zayıf ve fakirlere yardım etme yükümlülüğüne ilişkin açık mesajı, bazı katılımcılar tarafından iyilik yapmanın ibadetin doğasında ve bir parçası olduğu bilinciyle anlaşılarak yorumlanmıştır. Katılımcılardan birinin ifadesi şöyledir:

Ben bir Müslümanım ve İslam'ın da belirttiği gibi, hayatımı Allah'a adamalıyım, yaşamım da ölümüm de Allah için olmalıdır. Bunlar (sosyal çalışmalar) benim namazım ve duam gibidir.

Bu ifade, katılımcılar için İslami ritüellerin ve ibadetlerin hem ilahi bileşen hem de sosyal bileşen içerdiğini göstermektedir. Birinci bileşen genellikle Müslümanlar ve tanrıları 
arasındaki ilişki olarak tanımlanır ve Arapça "Hablün mine'l-Allah" terimidir; ikinci bileşen ise Müslümanlar ve diğer insanlar arasındaki ilişkiyi kasteder, Arapça “Hablun mine'nnâs"terimi olarak kullanılır.

Yukarıda görüldüğü gibi İslami öğretinin dünyevi ve dünyevi olmayan yönü arasında yakın bağlantı olduğu inancı, gerçekten de Müslümanların sosyal ve hayırseverlik faaliyetlerini yürütmelerinin başlıca nedenlerinden biridir. Katılımcılar tarafından en çok atıfta bulunulan bir başka İslami kaynak da "En iyi Müslümanın insanlığın geri kalanına en çok fayda sağlayan olduğu" (Sizin en hayırlılarınız insanlara en çok fayda sağlayanlardır) ifadesinin Peygambere ait olduğu iddiasıdır (Dârekutnî). Katılımcıların bu hadisten genel çıkarımlarının, iyi bir Müslüman hatta iyi bir insan olmaları için başkalarına yardım ederek özverili bir şekilde yaşamaları gerektiği yönünde olduğu anlaşılmaktadır. "Yardım" kelimesinin katılımcılar tarafından sadece ihtiyaç sahiplerine para veya diğer ihtiyaç duydukları malzemeleri sağlamak gibi sınırlı bir tanımlama olarak görülmediği de anlaşılmaktadır. Tam tersine, maddi açıdan bakıldığında katılımcıların çoğu kişisel olarak verecek pek bir şeyleri olmadığı halde zamanlarını camide aktif olarak ya da başkalarına yardım etmeye yönelik sosyal organizasyonlara katılarak geçirdiklerini belirtmektedir.

\begin{abstract}
Ben zengin ya da akıllı değilim. Ama ben iyi bir insan, başkalarına fayda sağlayan iyi bir Müslüman olmak istiyorum. Ben de bu organizasyona katılıyorum; çeşitli sosyal faaliyetleri yürütmek için zamanımı harcıyorum. Bunu 20 yıldır yapıyorum ve çeşitli roller üsteniyorum. Eskiden birçok programdan sorumluydum. Yaşılar için haftalık toplantılar düzenleyerek başladım, sonra tüm organizasyonların yetimhanelerini yöneterek devam ettim. Şimdi ise sosyal kısmın başında her şeyden sorumluyum. Bunları yapmak geceleri rahat uyumamı ve kendimi iyi hissetmemi sağlıyor.
\end{abstract}

Başkalarına, özellikle de zayıflara yardım etme amaçlı hayır işleri ve diğer iyilik çalışmaları yapmak Müslümanların ahiret hayatına olan inancıyla yakından bağlantılıdır. Nitekim katılımcıların bu çalışmaları gelecekteki “öbür dünya” hayatları veya ahiretteki sonsuz yaşamları için ihtiyaç duyacakları hazırlık olarak gördükleri anlaşılmaktadır. Katılımcılardan biri durumu şöyle ifade etmektedir:

Mesela ABD'ye veya farklı bir yere bir haftalık, aylık ya da bir yıllık bir seyahat planladığınızda bile pek çok şey hazırlamanız gerekiyor; valizlerce kıyafet, para hatta yiyecek...Burada bahsettiğimiz bir sonraki hayat; sonsuzluğa seyahatten bahsediyoruz. Bu dünyadaki hayatın geçiciliğini bildiğimiz için biz "hayat bir yudum su içercesine geçer" diyen Java atasözünü daima hatırlarız. Yani boş bir çanta ile gitmek mantıklı mı? Tüm bu işleri hayatım boyunca yapsam bile yeterli olur mu bilmiyorum!

Bir camide Üstad olan diğer katılımcı da benzer bir görüşü paylaşmaktadır:

Sosyal faaliyetlerde bulunuyorum çünkü bu benim ahiret için birikimim. Hayat çok kısa... Eğer bizden daha az şanslı olan kardeşlerimize biz yardım etmezsek kim yardım edecek? İtiraf etmek gerekirse bunları yapmak kolay değildir. Çünkü çoğu kez kendi işlerime ayırmam gereken zamandan fedakârlık yapmam gerekiyor.

İlginçtir ki katılımcılar bu öbür dünya yatırımlarını sosyal yatırımlar olarak görmektedirler. Onlara göre eğer bir kimse başkalarına yardım ederse diğerleri de yardıma ihtiyaç duyduğunda ona yardım edecektir. Böyle bir bakış açısı, bu yardım çevreden gelse de Allah'ın nihai yardım kaynağı olduğuna dayanan İslam inancında kaynaklanmaktadır. Bu nedenle Müslümanlar Allah'tan yardım ister ve herhangi birinden gelen yardımın da Allah'tan geldiğine inanır.

Katılımcılardan biri olan Üstad NR'nin sözleri şu şekildedir: " Zor durumda olan bir kardeşine yardım eden kişiye, kendisi de zor duruma düştüğünde Allah'ın yardım edeceğine inanıyorum. "

Uyuşturucu bağımlıları ile çalışan Üstad $\mathrm{AH}$ de aynı görüşü paylaşmaktadır: 
Uyuşturucu bağımlısı olan müracaatçılarla uğraşmak kolay değildir. Bazen ölüm kalım meselesi bile olabilir. Uyuşturucu kullanımına karışanların geçici olarak kaybolduğuna dair güçlü bir inancım var ve hayatlarını düzeltmelerine yardımcı olmak benim görevim. İnanıyorum ki iyilik ekersek iyilik biçeriz.

Yukarıda anlatılanlar, normatif düşüncelerin, yani dinin emirlerini yerine getirmenin ve Allah'ın buyruklarına uymanın, bir Müslümanın hayır işleri yapması ve sosyal görevleri yerine getirmesinin en önemli nedeni olduğunu göstermektedir. Öbür dünya inancına ilişkin bu yaklaşım, İslam da dahil olmak üzere tüm inananlar için ortak olmakla birlikte, İslami doktrinlerin zayıfları korumak ve onlara yardım etmeye yönelik çok sayıda mesaj ilettiği gerçeği - tarihin de gösterdiği gibi- kültürler arası sosyal hizmet uygulamaları açısından çok önemli olmuştur ve olmaya devam etmektedir. Bu bölümün daha önceki kısımlarında ele alındığı gibi, bugüne kadar yetimhaneler, okullar, engelli ve yaşlılara yönelik kurumlar, bağış kuruluşları ve hastaneleri de kapsayan birçok sosyal hizmet kurumu, sosyal ve dini kuruluşlar tarafından işletilmekte olup pek az sayıda kurum devlet tarafından yönetilmektedir.

\title{
Programlara Hükümet Desteği
}

Sosyal hizmet açısından belirtilmesi gereken, katılımcıların, camilerin ve sosyal-dini organizasyonların refah çoğulculuğu olarak adlandırılabilecek şeyin kurulmasında rol oynadığına inanmalarıdır. Bu kişilerin birçoğunun, hükümetin vatandaşları için geniş kapsamlı refah hizmeti sağlayabileceği konusunda ciddi şüpheleri bulunmaktadır. Onlara göre hükümet politikaları ve programlarının ulaştığı insan sayısı oldukça sınırlıdır. Tam da bu nedenle, birçok katılımc topluluğun katkısına çok ihtiyaç duyulduğuna inanmaktadır. Yetimhane için ücretsiz bir okul Kuran Lisa ve Heru, eğitim sisteminin birçok çocuğu marjinalleştirdiğini iddia etmektedir:

\begin{abstract}
Bütün çocuklar kendi tarzlarında dâhidir. Önemli olan fırsattır. Maalesef hükümetimiz bu fırsatı veremez. Özellikle yoksullar için eğitim sağlamayı umursamıyorlar. Tüm sözde iyi okullar çok pahalı! Bunu nasıl karşılayabilirsiniz? Hadi çocukları yalnız bırakalım (himayelerindeki yetimler). O çocuklar yiyecek bulduğunda bile kendilerini şanslı hissediyorlar. İşte bu yüzden bu okulları inşa etmeye karar verdik. Biliyor musunuz o zaman bile hükümet hiç destek vermiyor. Dinas'tan (Eğitim Bakanlığı)'ndan bu okulun ruhsatını almaya çalıştığımızda bizden milyonlarca rupi (para birimi) istiyorlar. Oradaki personele dedim ki: Sence sana ödeyecek paramız var mı? Okulları inşa etmek için gereken parayı biriktirmek uğruna benim ve ailemin aç kalması gerekiyor ve siz yapmanız gereken iş için bizden para mı istiyorsunuz? Bu hizmeti başlatmak için ruhsat alma işini unuttum (vazgeçtim) ve bu çocuklara eğitim vermeye devam ettim.
\end{abstract}

Katılımcıların kurumlarının rolüne ilişkin görüşleri yersiz değildir. Dini kuruluşlar halen eğitim, sağlık ve sosyal hizmetlerin önemli sunucuları olmaya devam etmektedir. Hükümetler tarafından yönetilenlere kıyasla dini kuruluşlar tarafından yönetilen okul, hastane, yetimhane ve sosyal hizmet kurumu sayısı da daha fazladır.

\section{Rol Model Olma}

Bu çalışmaya katılan kadınlar, çocuklarına değerler eğitimi vermenin bir yolunun da iyi şeyler yapmak olduğuna, bu nedenle hayırseverlik işleriyle meşgul olarak çocukları için rol modeller olabileceklerine dair aynı inançları paylaşmaktaydılar. Bu kadınlara göre, çocuklar ebeveynlerinin başkalarına yardım etmesini izleyerek birçok olumlu değer öğrenirler. Maya adlı bir katılımcı, ailesi için sosyal çalışmaların bir aile etkinliği haline geldiğini belirterek çocukları dahil tüm ailesinin çalışmalara katıldığını ifade etmiştir. Ona göre, daha az şansı insanlarla çalışmak, çocuklarının empati duygusunu geliştirmiş ve ne kendisi ne de kocası tarafından söylenmeden hayır işlerinden keyif almalarını sağlamıştır. 
Lisa da benzer bir görüşle, ailesi ve kendisinin her gün yüzlerce yetime bakmak ve eğitmek için dayanmak zorunda oldukları zorlu çalışmaların, çocuklarına maddi değerlerden ziyade insanların çalışmalarına kıymet vermeyi öğrettiğini düşünmektedir. Ayrıca, bu faaliyetlerin ailesinin güçlü bağlar geliştirmesine yardımcı olduğu görüşündedir.

\begin{abstract}
Bence, ben ve eşimin her gün yetimhanedeki çocuklarımızın yiyecek bir şeyler bulması ve okuldaki öğretmenlerin ücretlerinin ödenmesi için gerekli parayı kazanmak uğruna yaptığımız mücadeleyi izlemek, onların destek ve fedakarlıklarına ihtiyacımız olduğu gerçeğini kendi çocuklarımızın hızlı öğrenmesine sebep oldu. Dolayısıyla, çocuklarımız daha fazla sorumluluk alacak yaşa gelir gelmez ekip olarak çalışabileceğiz ve bu ailemiz arasında çok güçlü bir bağ oluşmasını sağladı; bana göre diğer ailelerden daha güçlü bir bağ. Oğlum, eğitimine başka bir şehirde devam etmek için evden ayrıldığında zor zamanlar geçirdi, çünkü onun için daha fazla paraya ihtiyacımız olmasının yanı sıra, günlük işlerimize artık yardım edemeyeceğini de biliyordu.
\end{abstract}

Sosyal organizasyonun aile içinde nesilden nesile aktarılmasının yaygın nedenlerinden biri bu değerlerin çocuklara işlenmesi olabilir. Bu araştırmaya katılanların çoğu, aile işleyişinin bir parçası olarak küçük yaşlardan itibaren sosyal yardım faaliyetlerinde bulunduklarını belirtmişlerdir. Bu değerleri çocuklara öğretme yeteneği katılımcıların çoğuna göre önemlidir çünkü hayırseverlik çalışmalarının devam etmesi bu şekilde sağlanacaktır. Katılımcılara göre modern dünyanın, ağır okul programı gibi talepleri, internetin ve diğer araçların etkisi, başkalarına bakmak, çalışkan olmak gibi önemli değerleri çocuklarına işlemek isteyen ebeveynler için zor bir sorundur. Katılımcılar, çocukları daha yakından izlemenin ve sürekli olarak iyi davranışlara maruz bırakmanın onları eğitmenin en etkili yolu olduğunu düşünmektedirler.

\title{
Psikolojik Tatmin
}

Katılımcıların çoğu tarafından altı çizilen bir diğer nokta da başkalarına yardım etmenin psikolojik olarak tatmin edici bir çalışma olduğudur. Yardım ettikleri kişinin dönüşümünü izlemek ve bir kişinin hayatını değiştirme noktasında yaptıkları etkiyi anlamak, katılımcılar için sonsuz bir mutluluk kaynağı ve aynı zamanda işlerine devam etme gücüdür.

Bir camide Üstad olan Hasan'ın sözleri şöyledir:

\begin{abstract}
Yaptığım işin veya sözlerimin başkalarına uyanmaları ve ağır sorumluluklarından vazgeçmemeleri için ilham verdiğini görmek bana güç veriyor. Bildiğiniz gibi sosyal çalışmalar yapmak her zaman kolay değildir. İnsanlar olarak kendi sorunlarımız ve sınırlılıklarımız olabilir, diğer taahhütlerimiz, işimiz ve harcamamız gereken paradan bahsetmiyorum bile. Yine de işimin birini değiştirdiğini ve onun hayatına devam edebildiğini gördüğümde, kendi sorunlarımın havada kaybolduğunu hissetmeden edemiyorum. Başkalarına yardım etmeye bağımlı hale geldim.
\end{abstract}

Vurgulanması gereken, yukarıda belirtilen psikolojik tatminin, katılımcıların dini görüşlerinden ayrı tutulamayacağıdır. Bazı katılımcılar, başkalarına yardım etmenin insanlar tarafından Allah'a yaklaşmak olarak görülmesi gerektiğini, böylece cennet kapılarının açılacağını hissettiklerini belirtmiştir.

Özetlemek gerekirse, yukarıda tartışılan çeşitli konular, Müslümanların hayır işleri ve sosyal hizmet faaliyetleri yürütmesinin "dini nedenlerle" ya da dini görev ve sorumluluklarını yerine getirme gibi normatif nedenlerle sınırlı olmadığını göstermiştir. Bunun yerine katılımcılar kendileri veya aileleri ile ilgili başka daha "dünyevi" ve pratik nedenleri de vurgulamışlardır.

Dolayısıyla, din insanların hayır işleri ve sosyal aktiviteler yapmalarının ana nedeni olmasına karşın bu dini güdünün temellerinin de hayatın gerçeklerine dayandığı ve bu gerçeklerle bağlantılı olduğu sonucuna varmak daha güvenilir olacaktır. Diğer bir deyişle, 
bir kimse bu işleri yaparak sadece iyi bir Müslüman değil, aynı zamanda iyi bir insan olmayı hedeflemektedir. İnsanların günlük yaşamının gerçekliği ile, dünya ve öbür dünya arasındaki bağlantının varlığı, iyi şeyler yapmaya devam edileceğinin bir garantisi olarak görülebilir. Bu sadece dini bir çağrı değil, aynı zamanda insani yardım çağrısıdır. Özetle, sosyal hizmet faaliyetlerinde motivasyonun önemli anahtar kelimeleri şunlardır:

1) Balasan pahala (Allah'tan mükâfat)

2) Tabungan akhirat (Gelecek yaşam için yatırım; ahiret)

3) Hidup ini singkat (Hayat kısa)

4) Berkorban (Kurban)

5) Ibadah (ibadet)

6) Kebaikan (Iyilik)

7) Meluruskan kesesatan (Birinin hatasını düzeltmek)

8) Pengabdian (Bağlılık ve Özveri)

\section{Sonuç}

Endonezya dini temelinde tek Allah inancı olan bir ülkedir. Nüfusun çoğunluğunu oluşturan Müslümanlar, inanç temelli kurum veya kuruluşlarda görülen zengin İslami gelenek ve uygulamalara sahiptir. İnanç temelli birçok kurum ve din görevlileri ihtiyaç sahipleri için "Sosyal Hizmet" faaliyetleri yürütür. Camiler, dini organizasyonlar, İslami vakıflar, hocalar (Kyai veya Üstad), dini yol göstericiler / dini önderler veya onların takipçileri bunlar arasında sayılabilir. Sundukları hizmetler genellikle deneyimlerle başlatılır ve kendileri veya mahalli olarak bilge kabul edilen önderler tarafından yönlendirilir. Yardım aktörlerinin pek çoğu dini motivasyonla teşvik edilir. Bazıları ise insancıl duygularla ya da Batı'ı profesyonel sosyal hizmetlerle ilişkileri olmuş olabileceğinden mesleki nedenlerle motive olurlar.

"Sosyal Hizmet" faaliyetleri, hayır işleri, nakit yardımı, mikrofinans, sosyal hizmetler, sağlık hizmetleri, rehabilitasyon, toplum ve sosyal kalkınma ve güçlendirmeye kadar değişen çeşitlilikler göstermektedir. Bu faaliyetler çoğunlukla zekât, infak (bağış) ve sadaka ile finanse edilmektedir.

Akademik çevrelerde, hala Batı teorileri ve uygulamalarının hâkim olduğu sosyal hizmet çalışmalarını zenginleştirmeye yönelik olarak, Endonezya islam geleneklerini, iman ve inançlarını keşfetme konusunda artan bir farkındalık mevcuttur. İslami kuruluşlar, ümmeti özellikle yoksul insanları güçlendirmek amacıyla Kur'an-ı Kerim ve Hadis içindeki İslami değer ve felsefeye dayanan sosyal refah faaliyetleri düzenlemektedirler. Sosyal refah faaliyetlerinde yer alan bireyler (Kyai/Üstad, öğretmen/aktivist) çalışmalarını içsel motivasyona dayandırmaktadır.

Müslümanlar için İslam bir dinden daha fazlasıdır; yaşam için kapsamlı bir çerçeve sağlar. Profesyonel sosyal hizmet görevlileri, Müslüman toplum içindeki farklı dindarlık düzeylerine, dini uygulamalara ve geleneklere saygı göstermelidir.

\section{KAYNAKÇA}

Akimoto, T. (2013). Introduction: What can Buddhism contribute to the Professional Social Work? The Roles of Buddhism in Social Work: Vietnam and Japan. Japan: ACWelS 
Japan College of Social Work. http://id.nii.ac.jp/1137/00000207/ (retrieved 4th August 2015)

Barise, A. (2003). Toward indigenization of social work in the United Arab Emirates.

Paper presented at Advancing Indigenous Social Work Conference, organized by Universiti Malaysia Sarawak, Kuching, 20-21 Ekim 2003.

Canda, E.R. (1989) "Religious content in social work education: A comparative approach", Journal of Social Work Education, 25, pp. $15 \bigoplus 24$.

Canda, E.R. (1998) Spirituality in Social Work, Binghampton, NY, Haworth Press.

Canda, E.R \& Furman, L.D. (1999). Spiritual diversity in social work practice: The heart of helping. New York: The Free Press.

Dompet Zuafa. http://www.dompetdhuafa.org/ Erişim tarihi 10 Kasım 2015

EmoKastama.(1990).Inabahsuatu metod epenyadaran korban narkotika dengan menggunakan Zikrullah Thariqat Qodirriyah Naqsyabandiyyah di pondokpesantrensuryalaya. Tasikmalaya: PondokPesantrenSuryalaya, Jawa Barat, Indonesia.

Fahrudin, A. (2005) Spritualitasdan Agama Dalam Praktek PekerjaanSosial: Sebuah Konsepsi. Makalah disajikan dalam Diskusi Buku Spirituality within Religious Traditions in Sosial Work Practice, anjuranInstalasiPendidikan Agama, SekolahTinggiKesejahteraanSosial (STKS) Bandung, 5 Aralık 2005.

Fahrudin, A. (2013). Social Welfare and Social Work in Indonesia. In Dr Sharlene Furuto (ed.), Social Welfare and Social Work in Asia Pacific. New York: Columbia University Press.

Family for Every Child. (2013). Muhammadiyah and Family for Every Child have run a pilot of social work assessment tool, access from www.familyforeverychild.org, Erişim Tarihi 12 Ocak 2014.

Geertz, C. (1983). Local knowledge: Fact and law in comparative perspective. In Geertz, C. (Ed.), Local knowledge: Further essays in interpretive anthropology, pp. $167 Đ 234$. N.Y.: Basic Books.

Hall, R.E. (2012). Islamic spirituality vis-^-vis Asia Pacific Muslim population: A resource for Western social work practice. International Social Work, 55(1): 109124.

Hokenstad, M.C. \&Midgley, J. (Eds.). (1992). Issues in international social work:

Global challenges for a new century. Washington D.C: NASW Press.

Hook, M.V, Hugen, B. \& Aguilar, M. (2004). Spirituality within religious traditions in social work practice. Boston: Allyn and Bacon.

Inabah http://www.suryalaya.org/ Erişim Tarihi 31 Kasım 2015

Ife, J. (1997). Rethinking Social Work: Toward critical Practice. Australia: Addison wesley Longman Australia Pty Limited.

Latting, J.K. (1990). Identifying the ÒismeÓ: Enabling social work students to confront their biases. Journal of Social Work Education, 26, 36-44.

Modood, T., Bethoud, R., Lakey, J., Nazroo, J., Smith, P, Virdee, S. andBeishon, S.(1997) Ethnic Minorities in Britain: Diversity and Disadvantage. London: Policy Studies Institute. 
Model penyembuhanInabahhttp://www.suryalaya.org/inabah.html, Erişim Tarihi 29 Kasım 2015

Maududi, Abul A'la, Tafhim Al Quran, http://englishtafsir.com/Quran/107/index.html

Muhammadiyahhttp://www.muhammadiyah.or.id/ Erişim Tarihi 30 Kasım 2015

Muhammadiyah Disaster Management Center http://mdmc.or.id/ Erişim Tarihi 31 Kasım 2015

Nasution, H. (1990). Thoriqot Qodiriyyah Naqsabndiyyah: Sejarah, Asal Usuldan Perkembangannya. Tasikmalaya-Indonesia: Institut Agama Islam Latifah Mubarokiyah.

Nashir, H. (2010). Muhammadiyah gerakan pembaruan. Jogjakarta: Suara Muhammadiyah

National Association of Social Workers. (1999). Code of Ethics. http://www.socialworkers.org/pubs/code/default.asp (13 Eylül 2008)

Nelson, J. M. (2009). Psychology, Religion, and Spirituality. Valparaiso, USA: Springer Science + Business Media, LLC.

Law of Social Welfare No. 11 the year 2009

Singleton, S.M. (1994). Faculty personal comfort and the teaching of content on racial oppression. Journal of Multicultural Social Work, 3, 31-37.

Subandono, H. (2011). Kepemimpinan Kepala Sekolah Dalam Membentuk Motivasi Kerja Guru (StudiKasus di Sekolah Masjid Terminal DepokPropinsiJawa Barat). Unpublished, thesis in Universitas Indonesia.

Suyono, H.(2008, July). Empowering the community as an effort to revive the culture of self-reliance in community social security. Paper presented at 33rd Global Conference of ICSW, Tours, France.

Sekolah Gratis Master Indonesia. http://sekolahmaster.org/ Erişim Tarihi 10 Kasım 2015

Tamba, M.E.S. (2012). Proses Pelembagaan Sekolah Alternatif (Studi Kasus PKBM Yayasan Binalnsan Mandiri (YABIM)). Unpublished, thesis in Universitas Indonesia.

Zastrow, C. (2004). Introduction to Social Work and Social Welfare. 8th Edition. Belmont, CA: Brooks/Cole-Thomson Learning. 